\title{
Insensitivity of editors and indexers regarding the cultural variations of authors'
}

\section{surnames}

\author{
V. Raveenthiran \\ Department of Pediatric Surgery, SRM University, Kattankulathur, Chennai, Tamilnadu, India \\ Corresponding author: vrthiran@yahoo.co.in
}

\begin{abstract}
Surnames, although widely used, are not obligatory in many parts of the world. This communication describes the hurdles and humiliations suffered by Oriental and South Indian authors who do not have a surname. A novel solution to the problem of author surnames is also proposed.
\end{abstract}

Key words: author surname; editorial diversity; research integrity

Accepted: April 14, 2016

\section{Introduction}

"What's in a name? That which we call a rose By any other name would smell as sweet."

- William Shakespeare (Romeo and Juliet)

Shakespeare was lucky to have a surname. Had he shared my anguish, he would have written:

"It is all in the name; even if it smells very sweet A rose is a rose and can never be a jasmine.".

My agony is renewed every time I submit a manuscript for publication. Strangely, the source of my distress is nothing else but my own name. Journals never shy away from embarrassing me for not having a surname. Most of the Americans and Europeans have trinomial (first, middle and last names) or binomial names (first and last names). Online manuscript submission systems are apparently designed to suit trinomial naming. The tiny red asterisk of the registration page is sufficient to trigger my anxiety, for it declares that "given name" and "surname" are mandatory fields without which one cannot register with the system. Where do I go for a surname if I do not have one? How do I make western editors understand that we, south Indians, do not have a family name? We are simply known by our given names. Many other notable south Indian scholars have also shared this humiliation. When the young mathematical genius Ramanujan was to be enrolled as Fellow of Royal Society, he had to tell the registering clerk with much shyness: "Sir, really speaking I have no proper surname." (1).

\section{Is having a surname an obligation?}

In ancient times when people lived in hamlets, they knew each other individually and hence surnames were not needed. This is the reason why biblical characters including Moses, Mary, Joseph and Jesus have no surname. When people started living in crowded cities, the need for distinguishing two or more individuals with the same given name arose. Thus, surnames were introduced during $13^{\text {th }}$ century. They became established in the $15^{\text {th }}$ century, when King Henry VIII ordered births to be registered under father's surname (2). However, some tribes still manage to identify individuals without resorting to surnames. Place of ancestral origin, nature of occupation and relationship between individuals have been effectively used instead of surnames. For example, in the New Testament, "Mother Mary" is distinguished from "Mary of Magdalene" and "Joseph, the carpenter" 
is distinguished from "Joseph of Arimathea". Similarly, we - South Indians - have our own system of identifying people with similar given names.

\section{The origin of South Indian names}

Traditionally, South Indians prefix their given names with that of their fathers. In the case of women, after marriage, the father's name is replaced with the husband's given name. For added clarity, some of us include the place of ancestral origin prior to the father's name. Although, castename suffixes were in vogue during the last century, they are now considered a sign of caste discrimination and thus a legal offense. All the prefixes of given names are either abbreviated or expanded, while suffixes are invariably written in full form. Table 1 summarizes various patterns of South Indian names in which father's given name, place of origin and caste name are used instead of surnames.

\section{Online submission systems' insensitivity}

As per tradition of my clan, I prefer to write my name as "V. Raveenthiran", the initial ' $V$ ' being derived from my father's name "Venkatachalam". However, manuscript submission systems would not accept my registration without a surname. More importantly, there is no way one can appeal for special consideration.

Initially I felt humiliated and got annoyed. Subsequently, out of frustration, I tried pretending my father's given name as my surname. Obviously, a father's name is no substitute for surname. For this reason, writing my name as "Raveenthiran Venkatachalam" did not solve the problem. Not infrequently, editors reply with a salutation "Dear $\mathrm{Dr}$ Venkatachalam...."

I used to wonder as to why editors should treat me like a schoolchild, reporting to my father. I also used to amuse myself that my father must have

TABLE 1. Various styles of South Indian names

\begin{tabular}{|c|c|c|}
\hline Name of individual & Who's who & Naming style \\
\hline Subrahmanyan Chandrasekhar & Nobel Laureate in physics & FGN (Subrahmanyan) before PGN \\
\hline Venkatraman Ramakrishnan & Nobel Laureate in chemistry & FGN (Ramakrishnan) behind PGN* \\
\hline C.V. Raman & Nobel Laureate in physics & $\begin{array}{l}\text { FGN (Chandrasekhar) and first half of PGN (Venkata) are } \\
\text { abbreviated. } \\
\text { Venkataraman is the full given name }{ }^{\dagger}\end{array}$ \\
\hline G.N. Ramachandran & Discoverer of collagen structure & $\begin{array}{l}\text { PAO (Gopalasamudram) and FGN (Narayanana) are } \\
\text { abbreviated before given name. }\end{array}$ \\
\hline C. Rajagopalachari & Last Governor General of India & $\begin{array}{l}\text { FGN (Chakravarti) is abbreviated before given name } \\
\text { (Rajagopal) while the caste indicator (Achari) is written in full } \\
\text { form behind the given name }\end{array}$ \\
\hline Yellapragada Subba Row & Prolific inventor of many drugs & $\begin{array}{l}\text { Ancestral name (Yellapragada) and caste name (Row) })^{\ddagger} \text { are } \\
\text { added on either side of given name }\end{array}$ \\
\hline Muthulakshmi Reddy & First Woman doctor of India & Given name followed by caste name (Reddy) \\
\hline M.S. Subbulakshmi & Renowned Singer & $\begin{array}{l}\text { PAO (Madurai) and husband's name (Sadasivam) are } \\
\text { abbreviated before given name }\end{array}$ \\
\hline
\end{tabular}

FGN - father's given name, PGN - person's given name, PAO - place of ancestral origin.

*It is unusual for South Indians to write father's name behind their given names. Out of respect for elders, father's name is always written before one's own given name. Early migration to Western countries and peer pressure to have a surname could have influenced Venkatraman to adopt this westernized pattern of name.

† South Indian given names are often a combination of two independently meaningful words. Although they are written as one compound word, it is possible to split them for the ease of personal conversation. "Venkatraman" can be called as either "Venkat" or "Rama". Similarly, "Chadrasekhar" can be called as either "Chandra" or "Sekhar".

\#"Row" is a phonetic variation of the more common spelling "Rao". 
been lucky enough to earn an instant doctorate without even entering a medical college. Furthermore, Pubmed records are at risk of attributing my works to a fictional person "R. Venkatachalam" while in fact my father is "S. Venkatachalam". After much tribulation, I have now learnt to minimize confrontations by writing my name as "Venkatachalam Raveenthiran". Of course, I am still embarrassed by the compromise and compulsion of using my father's name as my given name!

\section{Confusion in indexing records}

Such name confusion in Pubmed records is indeed dangerous because it may facilitate suppression of research and publication misconducts. For example, the following two papers from my locality are considered a duplicate publication (3-5).

1. Gowda DJ, Agarwal $P$, Bagdi R, Subramanian B, Kumar M, Ramasundaram M, Paramasamy B, Khanday ZS. Laparoscopic cholecystectomy for cholelithiasis in children. J Indian Assoc Pediatr Surg 2009;14:204-6.

2. Deepak J, Agarwal P, Bagdi RK, Balagopal S, Madhu R, Balamourougane P. Pediatric cholelithiasis and laparoscopic management: A review of twenty-two cases. J Minim Access Surg 2009;5:93-6.

Authors of both the papers in that order are the same persons (except for the addition of Kumar and Khanday in the first paper). However, it is difficult to suspect identicalness because given name and patronymic name of each author are reversed in the two publications. Arbitrary assumption of surnames is the source of this serious confusion.

Recently a unique 16-digit Open Researcher and Contributor ID (ORCID) number was introduced for unambiguous identification of authors (6). It is even suggested that this number should be made mandatory for all authors (7). However, the problem of authors without a surname is not solved even by this new system because the very registration page of ORCID again insists on having a surname. The ORCID number may be a useful supplement; but it cannot replace author's name in publications because identification is not the same as identity. ORCID number may facilitate unequivocal identification of individuals but the identity of authors still rests with their names.

It is reassuring that I am not the only person facing and voicing concerns of surname ambiguity. In 2008, 3 female researchers (Nalini, Jeevananthinee and Sujatha) wrote an agitated letter in "Nature" (8). They pleaded the journal editors to give South Indian authors their true name. Ironically, their letter is now displayed in Pubmed under their fathers' names (Puniamoorthy, Jeevanandam and Narayanan Kutty, respectively). I also understand that the problem of surnames is not unique to South Indians, but is shared by many Oriental and Arab communities (9). For example, Chung has written more than 10 editorials in various journals explaining the basic differences between Chinese and Western surnames (10). Chinese, probably as a sign of respect for their elders, place surname in the beginning of their name (first name), while Westerners use it at the end (last name). Compounding the confusion, the 1979 United Nations convention on the "Elimination of all forms of discrimination against women" endorsed the usage of mother's name (or surname) either in addition to or instead of father's name (or surname).

\section{Proposed solution}

Online registration pages of scholarly journals should be flexibly designed to suit various patterns of naming in different cultures. It can be simply achieved by abandoning the stereotypic terminology of "First Name, Middle Name and Last Name" in favour of "First order Name, Second order Name, Third order Name" etc. 'First name' is traditionally considered synonymous with 'given name'. On the other hand, "first order name" simply means that it stands first in the sequence. Thus "first order name" may mean surname to Chinese, father's name or place of origin to South Indians or 'given name' to Westerners. To put it in other words, the proposed modification of terminology simply identifies the components of a name-string by their numerical position without drawing any inference as to their origin or meaning. Authors with more than one 'given name' or two surnames will 
also find this new system convenient. For example, had this been in vogue, professor Thirumalaikolundusubramanian need not have squeezed all his three given names - Thirumalai, Kolundu and Subramanian - into a single box of registration page and earned the dubious distinction of having the longest author name in Pubmed records. Similarly, Bhaskar Dasgupta need not have stuffed his two surnames "Das" and "Gupta" into a single surname box. According to the proposed modification, he could have very well identified "Das" as second order name and "Gupta" as third order name.
Author registration pages must have provisions for 5 to 6 orders of names because such lengthy names are common among some Asian tribes. An adjoining box may be checked to indicate which is - or which are - the given name(s) (Figure 1). Alternatively, a drop-down menu adjoining each of the name components may facilitate the categorization whether it is a given name, surname, patronymic name, maternal name, place of origin, conjunction, honorifics or otherwise. Conjunctional components of names such as 'da' in 'Leonardo da Vinci' and 'bin' in 'Mohammed bin Tughluq' can

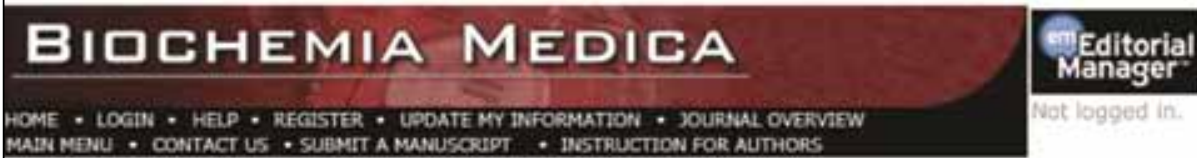

\section{Pre-registration Page}

To register to use the Editorial Manager system, please enter the requested information. Upon successful registration, you will be sent an e-mail with instructions to verify your registration.

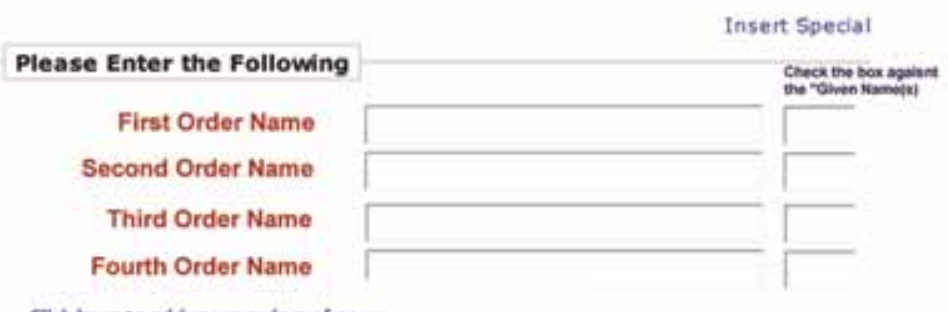

Cick here to add more ordess of name

"Authors should enter the name components according to their social custom. "First Order Name" need not necessarily be the "given name". Indicate the given name(s) by checking the box adjacent to the name bar

Preferred Appearance of Name in Print

Preferred Title and Name for addressing

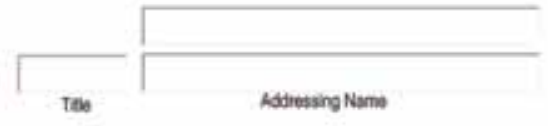

E-mail Address*

ORCID

What is ORCro?

WARNING - If you think you aiready have an existing registration of any ty Reviewer, or Editor) in this system, please DO NOT register again. This will delays or prevent the processing of any review or manuscript you submit. unsure if you are already registered, click the 'Forgot Your Login Details?'

If you are registering again because you want to change your current infor changes must be made to your existing information by clicking the "Update Information' link on the menu bar. If you are unsure how to perform these please contact the editorial office.

\section{Cancel Forgot Your Login Detals? Continue $>>$}

Figure 1. Suggested appearance of the author's registration page of the "Biochemia Medica" journal with implementation of the proposed modifications.

The terminology using "First Name, Middle Name and Last Name" is replaced with the terms "First order Name, Second order Name, Third order Name" etc. The proposed modification simply identifies the components of a name-string by their numerical position without drawing any inference as to their origin or meaning. 
thus easily be accommodated as second order name without confusing it with the middle name of Westerners. Von Recklinghausen could assign "von" as the first order name, yet designate it as a sign of nobility and thus avoid being mistaken for a given name.

The registration page should also ask the author's preference as to how his/her name should appear in print and as to how he/she should be addressed (Figure 1). No individual will ever prefer to write his/her name in more than one way. Thus asking the author's preference will eliminate the ambiguity introduced by editorial and indexing staff by arbitrarily assuming the last mentioned name as sur-

\section{References}

1. Kanigel $R$, editor. The man who knew infinity - $A$ life of the genius Ramanujan. New York: Washington Square Press; 1991.p.11.

2. McKie D, editor. What's in a Surname? A Journey from Abercrombie to Zwicker. New York: Random House 2013.

3. Gowda DJ, Agarwal P, Bagdi R, Subramanian B, Kumar M, Ramasundaram $M$, et al. Laparoscopic cholecystectomy for cholelithiasis in children. J Indian Assoc Pediatr Surg 2009;14:204-6. http://dx.doi.org/10.4103/0971-9261.59602.

4. Deepak J, Agarwal P, Bagdi RK, Balagopal S, Madhu R, Balamourougane P. Pediatric cholelithiasis and laparoscopic management: A review of twenty-two cases. J Minim Access Surg 2009;5:93-6. http://dx.doi.org/10.4103/09729941.59306.

5. Udwadia TE. Retraction notice. J Min Access Surg 2011;7: 125. names. For the same reason indexing agencies like Medline should use author's preferred print name instead of the obsessively compulsive usage of surnames.

In conclusion, journal editors, publishers and indexers should understand and respect the cultural variations in the pattern of authors' names. This is not only essential to avoid name confusions in medical literature but also to uphold the self-respect and dignity of authors. Are the concerned persons listening? Will they do it?

\section{Potential conflict of interest}

None declared.
6. Haak LL, Fenner M, Paglione L, Pentz E, Ratner H. ORCID: a system to uniquely identify researchers. Learned Publishing 2012;25:259-64. http://dx.doi.org/10.1087/20120404.

7. Anstey A. How can we be certain who authors really are? Why ORCID is important to the British Journal of Dermatology. Br J Dermatol 2014;171:679-80. http://dx.doi. org/10.1111/bjd.13381.

8. Puniamoorthy $N$, Jeevanandam J, Narayanan Kutty S. Give south Indian authors their true names. Nature 2008;452:530. http://dx.doi.org/10.1038/452530d.

9. Qiu J. Scientific publishing: identity crisis. Nature 2008;451:766-7. http://dx.doi.org/10.1038/451766a .

10. Cheng TO. The continuing confusion in figuring out the surname of a Chinese author - A proposed solution. Chin J Integr Med 2012;18:243-44. http://dx.doi.org/10.1007/ s11655-012-1061-7. 